\title{
Primary Source Notation
}

In order to simplify the text, conventional footnoting was abandoned in favor of symbols for the following primary sources. Citations in the text include source and page.

HC Hunter Report: Parliamentary Papers (Commons), 1920, vol. 14 (Reports, vol. 6), Cmd. 681, "Report of the Committee Appointed by the Government of India to Investigate the Disturbances in the Punjab, etc."

DC District Report: Parliamentary Papers (Commons), 1920, vol. 14 (Reports, vol. 6), Cmd. 534, "District Accounts Submitted by the Government of the Punjab."

INC Indian National Congress Punjab Subcommittee, Report of the Commissioners, 2 vols. (Bombay: Karnatak Press, 1920).

PDC Parliamentary Debates (Commons), 5th series, vol. 131 (28 June 1920-16 July 1920).

PDL Parliamentary Debates (Lords), 5th series, vol. 41 (6 July 1920-16 August 1920). 
